\title{
超臨界流体の溶解力と抽出技術への応用
}

\section{Solvent Power of Supercritical Fluid and its Application to Extraction Technique}

\section{佐古 猛 \\ 静岡大学創造科学技術大学院 \\ T 432-8561 \\ 静岡県浜松市中区城北 3-5-1}

Takeshi Sako

Graduate School of Science and

Technology, Shizuoka University

3-5-1 Johoku, Naka-ku, Hamamatsu 432-8561, JAPAN
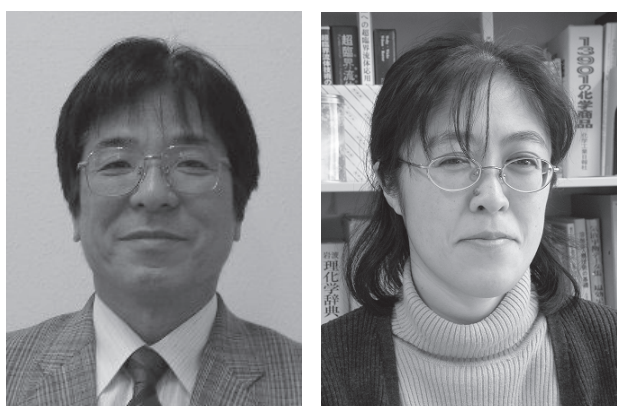

論文要旨：超臨界流体抽出技術は，対象物の熱変性や対象物中への有害な有機溶媒の残留といった問題を 生じない分離技術であり，食品や医薬品関係の分離に適している。超臨界流体は大きな溶解力と高い浸透性 という液体と気体の両方の性質を持っているので, とりわけ固体の天然物中の有用成分の抽出や不要成分の 除去等に適している。更に超臨界流体抽出とクロマト分離や還流操作を組み合わせると, 混合物中の特定成 分の濃縮が可能である。

天然物中の有用物質の超臨界流体抽出の例として, 大豆油, 生理活性物質を含む菌体生産油脂, 天然香料 の分離を取り上げた。また特定成分の濃縮の例として, 油脂をエステル化した後, 生理活性を持つ高度不飽 和脂肪酸エステルを超臨界流体クロマトグラフィーや還流付き超臨界流体抽出法で分離する方法を説明し た。

\begin{abstract}
Supercritical fluid extraction is an excellent separation technique which can avoid the heat denaturation of target materials and the residue of toxic organic solvent. It suits for the separation of food and pharmaceutical industries. Supercritical fluid has both large solvent power and high permeability and it can extract either a valuable or a toxic component from solid natural products selectively. Furthermore the concentration of a specific material is possible, when combining chromatographic separation or reflux operation.

The separation of soybean oil, bioactive oil produced from fungus and flavor ingredient was explained as an example of the extraction of valuable materials in natural products. The purification of highly unsaturated fatty acid such as $\gamma$-linolenic acid and EPA was discussed using supercritical fluid chromatography or supercritical fluid extraction with reflux as an example of the concentration of useful components.
\end{abstract}

Key words: supercritical fluid, solubility, extraction, soybean oil, highly unsaturated fatty acid, flavor

\section{1 はじめに}

超臨界流体抽出法は，加熱することなく目的成分を分 離できる, 抽出速度が速い, 製品中に有害な溶媒の残留 の心配がないといった利点により, 食品, 化粧品, 医薬

連絡者：佐古 猛

E-mail : ttsako@ipc.shizuoka.ac.jp
品関係の分離への応用が進められている ${ }^{1,2)}$ 。特に超臨 界二酸化炭素を用いる抽出法は, 有害な有機溶媒を用い ない天然物中の有用成分の抽出技術として, 日本, 韓国, 中国，欧米諸国等において活発に研究開発が行われてい る。工業化された代表例として，ビールに添加している ホップエキスの抽出やコーヒー豆からの脱カフェインが よく知られている。ここでは 2 章で超臨界流体の溶解特 
性と超臨界流体抽出法の原理，3 章で天然物中の生化学 物質の分離に応用した例を示す。

\section{2 超臨界流体の溶解特性と抽出法の原理}

\section{$2 \cdot 1$ 超臨界流体抽出法の原理}

超臨界流体とは，臨界温度および臨界圧力を超えた状 態の流体のことであり，この流体を抽出溶媒として固体 あるいは液体中の有用成分を抽出分離する操作を超臨界 流体抽出法とよぶ。この抽出法では純物質または混合物 の超臨界流体が用いられるが，ここでは純物質の場合に ついて説明する。Fig. 1 に純物質の圧力 - 温度線図を示 す。図より，物質は温度，圧力条件により固体，液体， 気体と様々な状態で存在する。ここで超臨界流体は図中 の斜線で示される領域の物質である。この流体は臨界温 度 $\left(T_{c}\right)$ ，臨界圧力 $\left(P_{c}\right)$ を超えた高圧で高密度の物質 であり，圧力を高くしても液化しない非凝縮性の濃い気 体といえる。実際の抽出に用いられる超臨界流体は斜線 部分の中でも臨界温度に近い領域, すなわち $T_{r}=1 \sim 1.2$, $P_{r}=1 \sim 5$ の範囲のものが多い $\left(T_{r}=T / T_{c}, P_{r}=P / P_{c}\right.$, ここで $T, P$ は抽出温度および圧力, $T_{c}, P_{c}$ は物質の 臨界温度と臨界圧力であり， $T, T_{c}$ はケルビン単位， $P$ と $P_{c}$ は同じ圧力単位を用いる)。

臨界温度をわずかに超えた超臨界流体中の溶質の溶解 度と圧力の関係を Fig. 2 に示す。図からわかるように, 臨界温度よりもわずかに高い温度 $\left(T \geq T_{c}\right)$ の条件下で は，溶質の溶解度は臨界圧力の前後で大きく変化する。 このことから臨界圧力を超えた高圧域で溶質を抽出し, 臨界圧力以下の低圧域まで減圧することにより溶質を抽 出流体から析出させるという分離プロセスが考えられ

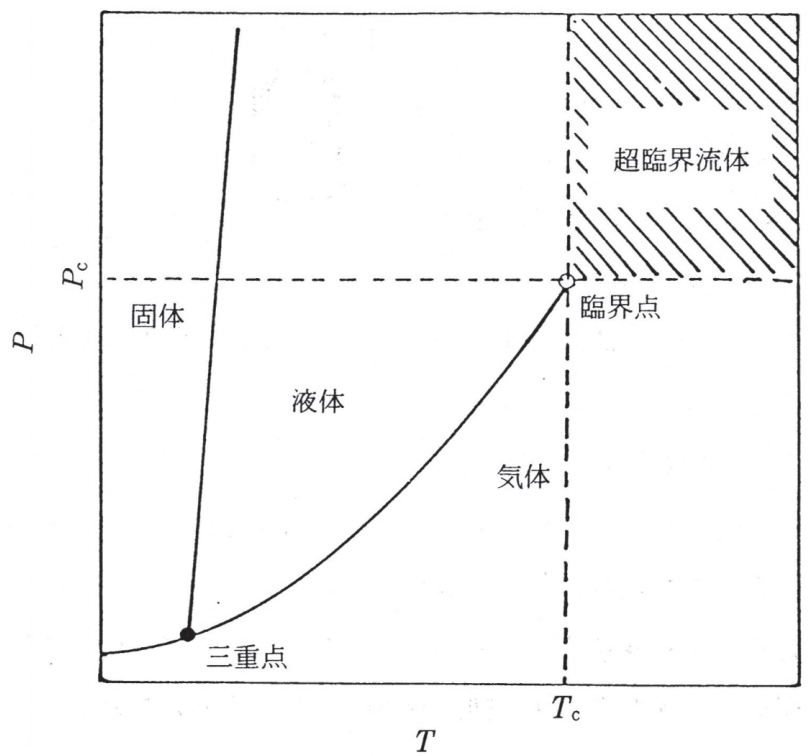

Fig. 1 純物質の温度 - 圧力線図

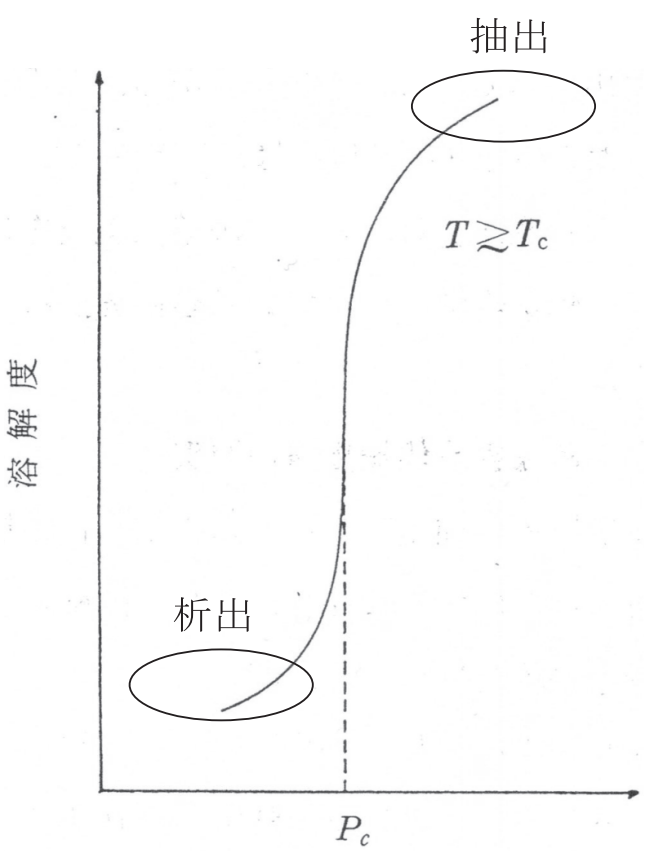

压力

Fig. 2 臨界温度付近の超臨界流体に対する溶質の溶解度の 圧力依存性

高圧側低圧側.

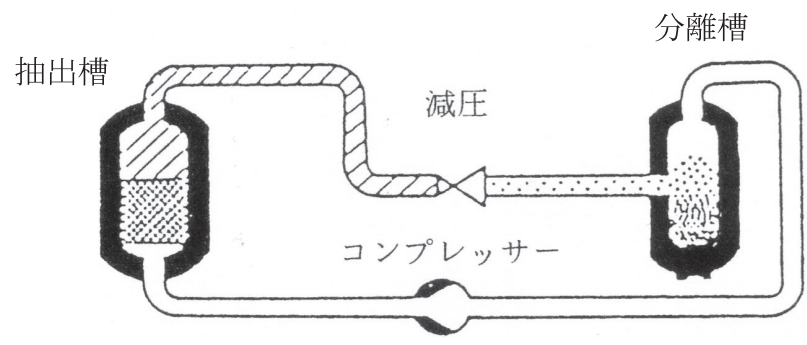

Fig. 3 超臨界流体抽出法の基本フロー（圧力変化法）

る。すなわちこれが超臨界流体抽出法の原理であり, 基 本的なフローを Fig. 3 に示す。ここで抽出流体から溶質 を析出させる方法は先ほどの減圧法のみでなく, 温度を変 化させて析出させる方法, 吸着材に溶質を吸着させる方 法, 窒素等の不活性ガスを添加して抽出流体の溶解力を 低下させて溶質を析出させる方法等が提案されている ${ }^{1)}$ 。

\section{$2 \cdot 2$ 超臨界流体中の溶解度}

なぜ超臨界流体は大気圧近辺の気体に比べて格段に大 きな溶解力を持っているのだろうか？これは両者の密度 の違いから説明できる。前述したように，超臨界流体は 高圧 ·高密度の非凝縮性の気体とみなせる。抽出流体の 密度が大きくなると，抽出流体とその中に溶けた溶質と の分子間引力の効果が大きくなり，より多くの溶質分子 が抽出されて流体中に安定に存在することができる。す 
なわち抽出流体と溶質の分子間相互作用が超臨界流体の 大きな溶解力を生じさせる最も重要な要因である。

超臨界流体中のある成分の溶解度を定量的に理解する ためには，相平衡についての熱力学を用いる必要があ る。相平衡の熱力学条件 (抽出流体中のある成分のフガ シチーと被抽出物中のその成分のフガシチーは等しい) から，超臨界流体中に溶けた成分 1 のモル分率単位の溶 解度 $y_{1}$ は,

$$
y_{1}=\frac{x_{1} \cdot \gamma_{1} \cdot P_{1}^{\mathrm{s}} \cdot \phi_{1}^{\mathrm{s}} \cdot \exp \left(\int_{p_{1}^{\mathrm{s}}}^{p} \frac{v_{1} d p}{R T}\right)}{\phi_{1} \cdot P}
$$

で表される。ここで $x_{1}$ は抽出される物質中の成分 1 の モル分率, $\gamma_{1}$ は活量係数, $P_{1}^{\mathrm{s}}$ は飽和蒸気圧, $\phi_{1}^{\mathrm{s}}$ は飽和 蒸気のフガシチー係数, $v_{1}$ は純成分 1 のモル体積, $R$ は 気体定数, $\phi_{1}$ は超臨界流体中に溶けた成分 1 のフガシ チー係数, $T, P$ は抽出時の温度と圧力である。簡単に するために, 抽出される物質は成分 1 のみからなる純物 質であり $\left(x_{1}=1\right)$, その揮発性が非常に低い $\left(\phi_{1}^{\mathrm{s}}=1\right)$, かつ被抽出物中への超臨界流体の溶解がほとんどない $\left(\gamma_{1}=1\right)$ と仮定すると，（1）式は以下のようになる。

$$
y_{1}=\frac{P_{1}^{\mathrm{s}} \cdot \exp \left(\int_{p_{1}^{\mathrm{s}}}^{p} \frac{v_{1} d p}{R T}\right)}{\phi_{1} \cdot P}
$$

上式から，溶解度に影響する因子は，(1)超臨界流体と抽 出される成分 1 の分子間相互作用 $\left(\phi_{1}\right)$, (2)抽出成分 1 の蒸気圧 $\left(P_{1}^{\mathrm{s}}\right)$, (3)抽出成分 1 に対する圧力効果 $((2)$ 式の分子の指数項), (4)温度 - 圧力の抽出条件 $(T, P)$ であることがわかる。

（2）式に基づいて，一定温度における溶解度の圧力依 存性について説明する。抽出流体が低圧（すなわち低密 度）で理想気体とみなせる場合には，（2）式の分子の指 数項と分母の $\phi_{1}$ は 1 であり, 溶解度 $y_{1}$ は $P$ の増加とと もに減少する。一方, 高密度の超臨界流体中では, 成分 1 と超臨界流体の分子間相互作用が大きくなる結果（す なわち, 超臨界流体相が理想気体近似から大きくずれ る), $\phi_{1}$ が非常に小さな值となる。この効果が $y_{1}$ の増大 に中心的な寄与をする。一例として， $35^{\circ} \mathrm{C}$ の二酸化炭素 中のナフタレンの溶解度の実測值と計算結果を Fig. 4 に 示す ${ }^{3)}$ 。温度が臨界温度よりもわずかに高い場合, 圧力 が臨界圧力に近づくに従い溶解度の実測值, 計算值共に 急激に上昇した。

次に一定圧力下における溶解度の温度依存性について 検討する。この場合には, 温度の上昇は成分 1 の蒸気圧 の増加をもたらす反面, 超臨界流体の密度の低下をまね

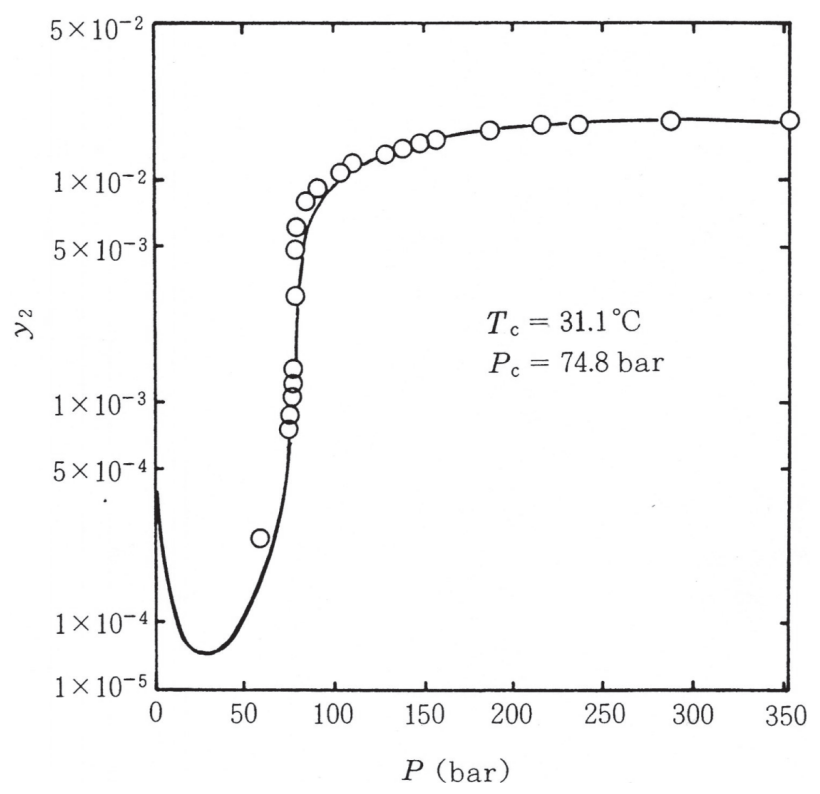

Fig. $435^{\circ} \mathrm{C}$ における高圧二酸化炭素中のナフタレンの溶解 度 $\bigcirc$ : Tsekhanskaya らの測定結果 - : 計算結果)

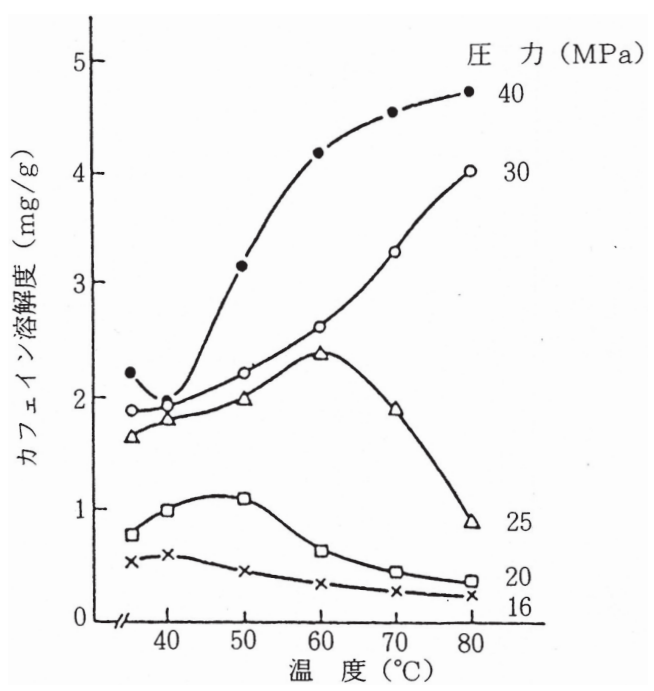

Fig. 5 超臨界二酸化炭素中のカフェインの溶解度の温度, 圧力依存性

くため, 少し複雑になる。一例として, 超臨界二酸化炭 素中のカフェインの溶解度を Fig. 5 に示す。臨界圧力か らあまり離れていない圧力下 $(16 \mathrm{MPa})$ では温度の上 昇とともに溶解度は減少し, さらに圧力が高くなると (30 MPa 以上) 温度の上昇とともに増加する。この傾 向は（2）式中の $\phi_{1}$ を状態方程式から計算することによ り予測できる。

もう一つ, 溶解度に対する温度と圧力の影響について の検討から, 大きな溶解度を得るためには温度は臨界温 度よりも少し高い領域（絶対温度で表した臨界温度から その 1.2 倍程度まで), 圧力はかなり高い領域（臨界圧 力からその数倍程度）が適していることが知られてい 
る。すなわちこの温度, 圧力の流体は超臨界流体の中で も温度が低く，圧力が高いので大きな密度，すなわち大 きな溶解力を持っている。一方, 臨界温度を超えている ので気体並みの拡散性を持っており, 固体中でも高速で 浸透する。すなわち固体の天然物中から有用物質を取り 出すのに適した抽出溶媒の特徵を持っている。

\section{2 -3 超臨界流体抽出法の特徵と超臨界流体の選定}

超臨界流体抽出法は, 従来の有機溶剂を用いる液液抽 出法の環境適応性と安全性を高め, 処理時間を短くする ために開発された技術である。超臨界流体抽出法の主要 な長所は, (1)超臨界二酸化炭素 $\left(T_{c}=31.1^{\circ} \mathrm{C}\right)$ や超臨界 エタン $\left(T_{c}=32.3^{\circ} \mathrm{C}\right)$ のような臨界温度が室温付近の抽 出流体を用いると室温付近での抽出および脱溶媒がで き, かつ抽出流体の溶質中への残留の恐れもない, (2)抽 出流体の溶解力は温度や圧力により容易にコントロール できるので，異なる組成の抽出物を順次析出させていく ことが可能である，(3)抽出速度が速い，(4)最も用いられ ている超臨界二酸化炭素は無害, 不燃性, 安価, 入手が 容易である等である。一方，(5)液液抽出法に比べて抽出 流体の溶解力が小さいために，多糖類やタンパク質のよ うな高分子を抽出できない, (6)高圧の分離装置を建設す るための費用がかかる等の短所がある。

超臨界流体抽出を行う場合, どのような流体を抽出流 体として用いるのかを決める必要がある。以下に抽出流 体を選定する際の大まかなガイドラインを示す。

(1)大きな溶解力を有する抽出流体を用いる。（2）式の $\phi_{1}$ が小さくなるような流体を選定しなければなら ない。大ざっぱな指針として，抽出流体の臨界温度 が抽出温度に近い超臨界流体ほど大きな溶解力を持 ち, 同程度の臨界温度を持つ流体間では, 溶質と化 学的構造が似ている流体ほど大きな溶解力を持つ。

(2)化学的に安定であり，毒性や腐食性がない流体を用 いる。

(3)臨界温度が適当であること。臨界温度付近で抽出操 作を行うので，臨界温度が高いと溶質の変質や分解 が起こる危険性がある。

(4)容易に入手でき, 安価であること。

天然物中の生化学物質の抽出では, その熱安定性から 考えて室温付近の臨界温度を持つ抽出流体を用いるのが 望ましい。代表的な抽出流体は, 臨界温度が $31.1^{\circ} \mathrm{C}$ の超 臨界二酸化炭素である。

\section{$2 \cdot 4$ 抽出流体としての超臨界二酸化炭素の特徵}

天然物中の有用物質の抽出では超臨界二酸化炭素が最 も用いられている。この流体は溶解力の大きさの点でや や不満足であるが，無害で化学的に安定である，室温付 近で抽出を行うことができる，拡散性が大きい，容易に
入手できて安価であるといった多くの利点を持ってい る。このために生化学物質関連の超臨界流体抽出は, 超 臨界二酸化炭素を用いて $35 \sim 60^{\circ} \mathrm{C}$ の条件でなされてい るのが大部分である。Stahl は超臨界二酸化炭素中の様々 な物質の溶解度を測定し, 次のような経験則を報告して いる ${ }^{4)}$

(1)炭化水素, エーテル, エステル, ラクトン, エボキ シド等の極性の低い化合物は, 7〜10 MPa 程度の 低圧で抽出可能である。

(2) $\mathrm{OH}$ 基, $\mathrm{COOH}$ 基のように極性が高い官能基の数 が増加すると, 超臨界二酸化炭素による抽出が困 難になる。芳香族化合物では, フェノール性 $\mathrm{OH}$ 基が 3 個，あるいは $\mathrm{COOH}$ 基が 1 個と $\mathrm{OH}$ 基 2 個 が抽出限界である。

彼が指摘しているように，超臨界二酸化炭素はあまり 大きな溶解力を持っていないので抽出対象物に対してか なり制約がある。一方で低い溶解力が混合物中の特定成 分の抽出を可能にしている。例えば油脂混合物から中性 脂質を選択的に抽出し, リン脂質等の極性脂質をほとん ど抽出しないというのはその一例である。一方, 超臨界 二酸化炭素にアルコールや低級炭化水素を添加して, そ の溶解力を高めようとする研究も数多く行われている ${ }^{5)}$ 。

\section{3 生化学物質の分離・精製への応用例}

生化学物質の分離に超臨界流体抽出法を適用した例 は, 食品工業を中心に多数みられる。発表された文献や 特許からその対象をまとめると Table 1のようになり， 天然物中の有用成分を超臨界二酸化炭素を用いて抽出分 離している例が多い6)。ここでは超臨界流体抽出の応用 例として, 脂質と天然香料の抽出を取り上げて説明す る。一方, 超臨界流体抽出法では目的成分の純度を 100\%近くまで上げることは難しい。そこで次の技術と して超臨界流体を用いた特定成分の濃縮・精製技術が必 要となる。一例として, 超臨界流体を用いた高度不飽和 脂肪酸の分離・精製について説明する。

\section{$3 \cdot 1$ 脂質の抽出とエントレーナー効果}

1980 年代以降, 超臨界流体を用いて天然物中の脂質 を抽出する研究が行われている。対象物としては，植物 種子, 魚介類や藻類などの水産物, 菌体生産脂質等広い 分野にわたっており, 通常, 超臨界二酸化炭素により抽 出を行っている ${ }^{6)}$ 。ここでは大豆中の食用油の抽出と, 菌体生産油脂の抽出に及ぼすエントレーナー効果につい て説明する。

現在, 植物油の抽出では圧搾法と液液抽出法が用いら れているが，前者は油分の回収率が低いこと，後者では ヘキサン等の可燃性の有機溶媒を用いることや油分中の 
Table 1 超臨界流体抽出法の生化学物質の分離への応用例

\begin{tabular}{|c|c|}
\hline 医薬品工業 & $\begin{array}{l}\text { 酵素, ビタミンなどの精製, 回収 } \\
\text { 動植物からの薬効成分の抽出（アルカロイド，トコフェロール，精油など） } \\
\text { 医薬品原料の濃縮, 精製, 脱溶剂 } \\
\text { 脂質混合物の分離精製（グリセリド, 脂肪酸, レシチン） } \\
\text { 䁔母, 菌体生成物の抽出 }\end{array}$ \\
\hline 食品工業 & 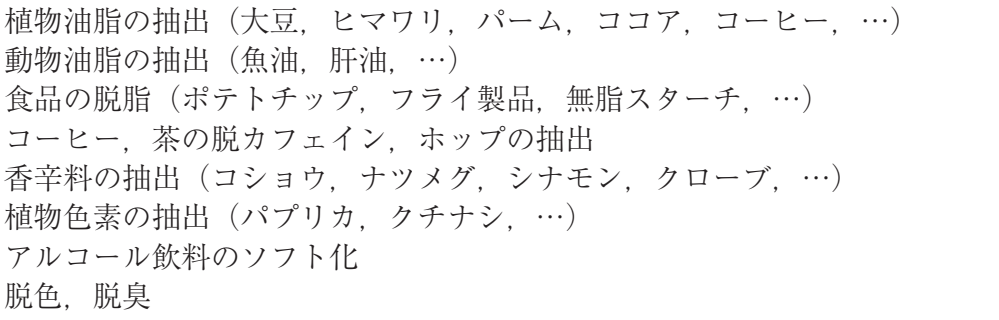 \\
\hline $\begin{array}{c}\text { 香料工業 } \\
\text { 化粧品 }\end{array}$ & $\begin{array}{l}\text { 天然香料の抽出, 合成香料の分離, 精製 } \\
\text { タバコの脱ニコチン } \\
\text { 化粧品原料の抽出, 精製（界面活性剂, 脂肪酸エステル，モノグリセリド） }\end{array}$ \\
\hline
\end{tabular}

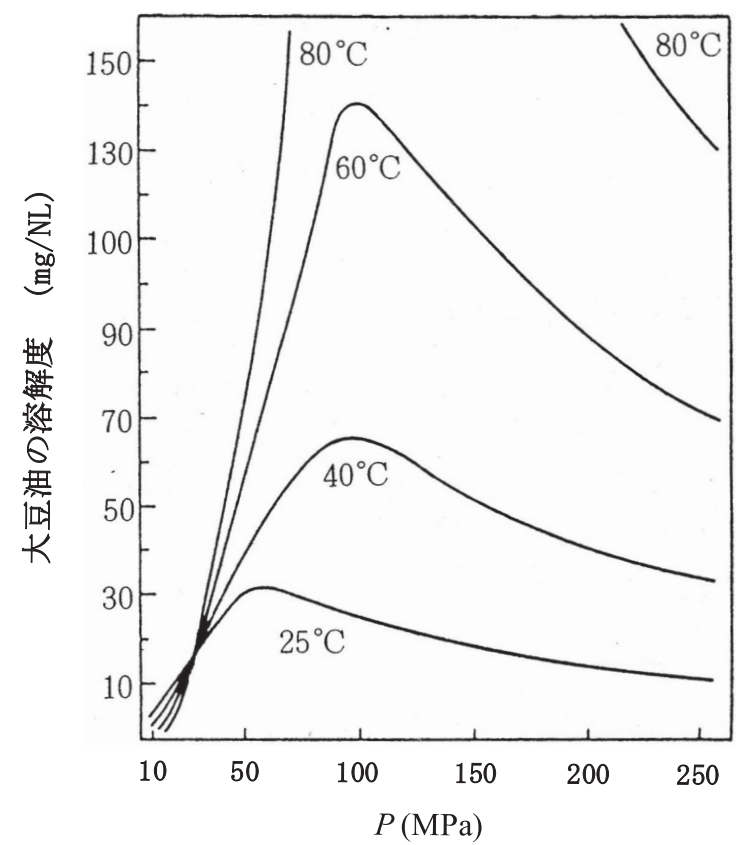

Fig. 6 超臨界二酸化炭素 $\left(40^{\circ} \mathrm{C}\right.$ 以上) と液体二酸化炭素 $\left(25^{\circ} \mathrm{C}\right)$ 中の大豆油の溶解度の比較

残留溶媒の除去に多量の熱エネルギーが必要といった問 題がある。これに対して超臨界流体抽出法ではこれらの 欠点を解決可能である。Fig. 6 に, 超臨界二酸化炭素 $\left(40^{\circ} \mathrm{C}\right.$ 以上) と液体二酸化炭素 $\left(25^{\circ} \mathrm{C}\right)$ 中の大豆油の溶 解度と温度, 圧力の関係を示す ${ }^{7)}$ 。 $35 \mathrm{MPa}$ 以下の圧力 では液体二酸化炭素の方が超臨界二酸化炭素よりも大き な溶解力を示すが, それ以上の圧力では逆転する。また いずれの温度においても高圧側で溶解度の極大值が存在 する。更に実際の抽出操作では原料の破砕の程度や原料 中の水分含有率など原料の前処理の程度が抽出効率に大 きな影響を与える。Figs. 7, 8 に大豆油の抽出量に対す

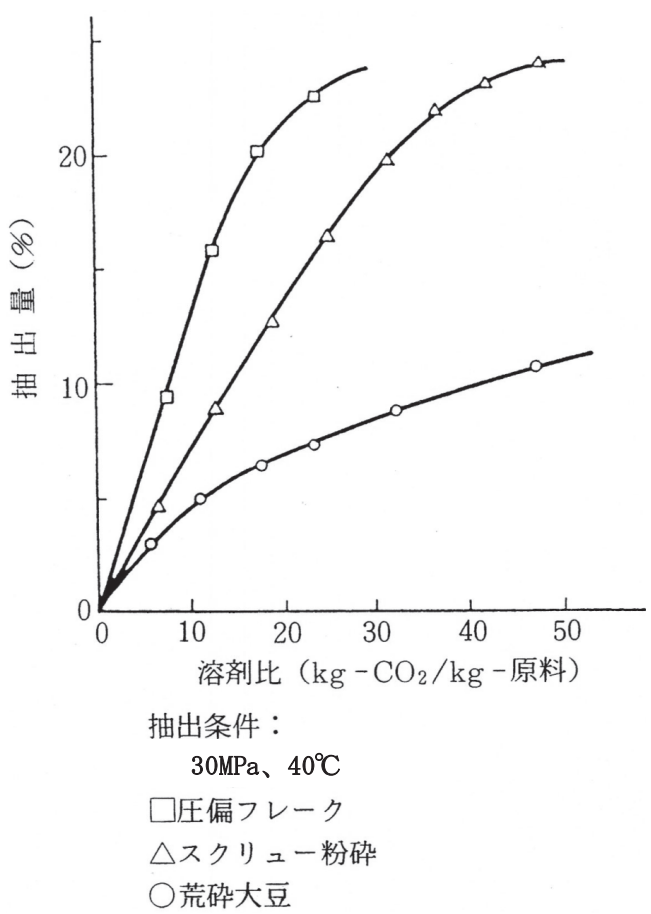

Fig. 7 超臨界二酸化炭素による大豆油の抽出における原料 粒径の影響

る原料の粒径や原料中の水分含有率の影響を示す。超臨 界流体は一般の有機溶剂に比べて物質への浸透性がよい といわれているが, ある程度の破砕は抽出率の向上のた めに不可欠である。また水分含有率が高く油分が水で包 まれているような状態では抽出率は極端に低くなるた め, 原料をあらかじめ乾燥しておく必要がある。超臨界 二酸化炭素で抽出した油と $\mathrm{n}$-ヘキサンで液液抽出した 油の脂質組成を比較したところ, 前者では中性脂質が選 択的に抽出されており, リン脂質, 着色成分の量はn- 


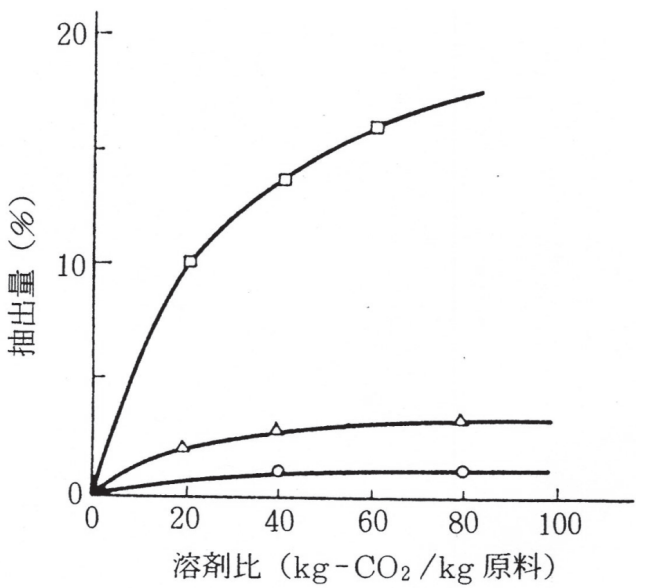

抽出条件 $30 \mathrm{MPa} 、 60^{\circ} \mathrm{C}$

$\square$ 乾燥大豆
$\triangle 30 \%$ 湿大豆
$\bigcirc 50 \%$ "

Fig. 8 超臨界二酸化炭素による大豆油の抽出に㧍ける水分 の影響

ヘキサン抽出から得られた油よりもずっと少ない。この ことから, 超臨界二酸化炭素で抽出すると, 後の脱ガム, 脱色, 脱臭工程が省略あるいは簡略化できる可能性が高 い。

次に油脂の抽出に対するエントレーナー効果につい て，菌体生産油脂についての私達の実験結果を基に説明 する ${ }^{8)}$ 。Stahl が指摘しているように，超臨界二酸化炭 素は溶解力があまり大きくないことが久点としてあげら れる。このためにエントレーナーと呼ばれる第 3 成分を 超臨界二酸化炭素に添加して溶解力や選択性を向上させ ることが試みられている。生化学物質の抽出では，安全 性を考慮してエ夕ノールや水等を用いることが多い。私 達は糸状菌が生産する $\gamma$ - リノレン酸含有油脂を超臨界 二酸化炭素及びこの流体に極性物質のエタノールや無極 性の n-ヘキサンを添加した流体で抽出し, 溶解力と選 択性に対するエントレーナーの効果を調べた。純粋な超 臨界二酸化炭素とエントレーナーを添加した超臨界二酸 化炭素中の油脂の溶解度の比較を Fig. 9, 抽出油脂中の 生理活性物質である $\gamma$-リノレン酸の濃度の比較を Fig. 10 に示す。エントレーナーの添加により超臨界二酸化 炭素の溶解力は大きく向上したが, $\gamma$-リノレン酸の選択 的濃縮はみられなかった。

\section{$3 \cdot 2$ 天然香料の抽出}

天然物から香料の抽出は, 通常, 圧搾法, 水蒸気蒸留 法, 液液抽出法などにより行われているが, 抽出率が低 い, 香料物質が熱により変化する恐れがある, 抽出剤の 除去の時に一部の香気成分が逃げてしまう等の問題があ

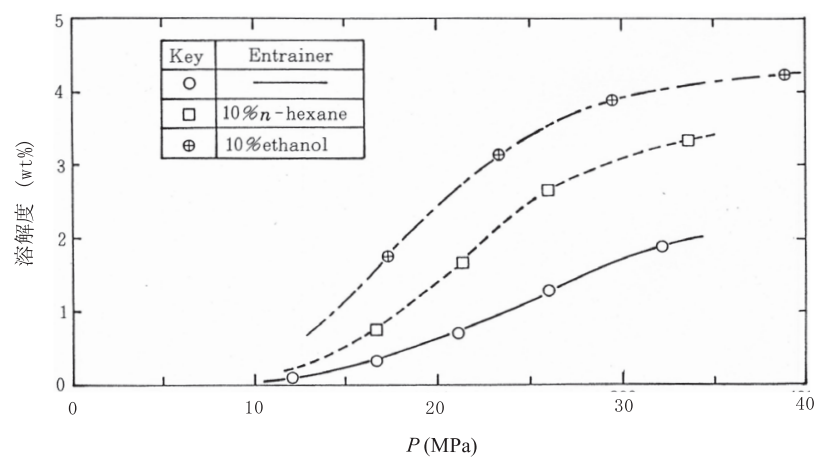

Fig. $960^{\circ} \mathrm{C}$ の超臨界二酸化炭素中の菌体生産油脂の溶解度 に対するエントレーナー効果

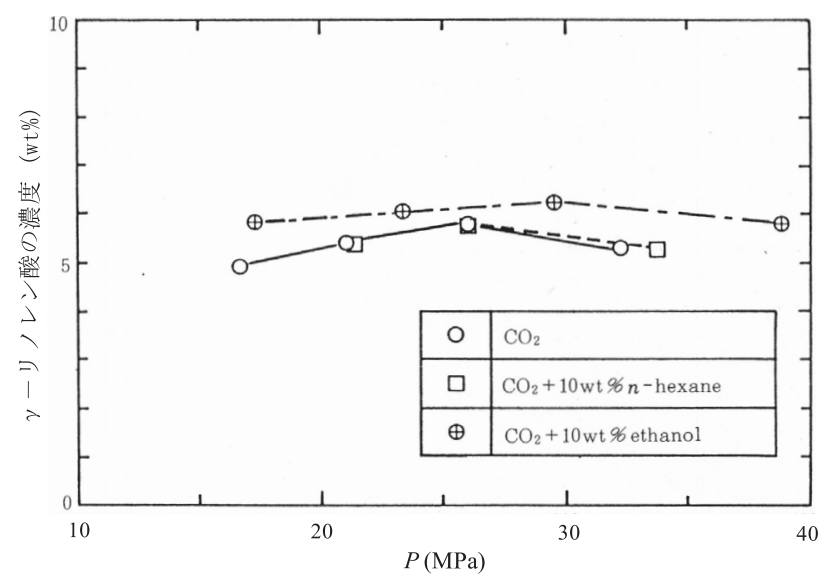

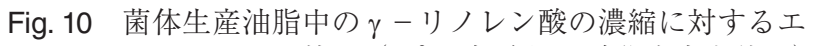
ントレーナー効果 $\left(60^{\circ} \mathrm{C}\right.$, 超臨界二酸化炭素を使用 $)$

る。このために超臨界二酸化炭素による常温下での抽出・ 分離が研究されている。

今までに報告された香料の抽出例を Table 2 に示す。 ペッパー, ジンジャー等の香辛料の抽出結果から判断し て, 抽出圧力が低いと香気に関与する精油分が主に抽出 され，圧力の増加とともに呈味に関与する成分が抽出さ れてくる。呈味成分が抽出され始める圧力は成分の分子 量や化学的性質に大きく依存するが, 大ざっぱにいって $10 \mathrm{MPa}$ 前後と考えられる。また $50^{\circ} \mathrm{C}, 35 \mathrm{MPa}$ の高圧 超臨界二酸化炭素でジンジャーを抽出した場合の抽出物 組成は, 塩化メチレンによる液液抽出法から得られる抽 出物組成と大差がないという実験結果は, その温度・圧 力下では二酸化炭素の密度が $0.8 \mathrm{~g} / \mathrm{cm}^{3}$ 以上になり大き な溶解力を持つようになったためと考えられる。しかし ながら香味に関係ない色素成分（おそらく極性物質と考 えられる）を溶かすほど溶解力が大きくないため, 抽出 物の着色の程度, 粘性ともに塩化メチレンの場合に比べ て小さく，エキスとして優れた性状を示している。

3 -3 超臨界流体による高度不飽和脂肪酸の分離・精製 今まで述べてきたような, 超臨界流体による抽出とそ 
Table 2 超臨界および液体二酸化炭素による香料関連物資の抽出例

\begin{tabular}{|l|l|c|}
\hline \multicolumn{1}{|c|}{ 抽出対象天然物 } & \multicolumn{1}{|c|}{ 抽出成分 } & 条件* \\
\hline 果汁, エッセンス & アルコール, エステル, アルデヒド, ケトン & SC. Liq. \\
ペッパー & 精油, ピペリン & SC. \\
チリペッパー & 精油, カプサイシン & SC. \\
クローブ & 精油, オイゲノール & SC. \\
シナモン & 精油, シンナミックアルデヒド, オイゲノール & SC. \\
ナッメグ & 精油, トリミリスチン & SC. \\
ジンジャー & 精油 & SC. Liq. \\
ピメントベリー & 精油, オイゲノール & SC. \\
バニラビーンズ & 精油, バニリン & SC. \\
ジュニパベリー & 精油 & Liq. \\
ライラックの花 & 精油, ベンジルベルゾエート & SC. \\
ホップ & 精油, $\alpha-$ 酸 & SC. Liq. \\
ワイン & エステル, アルコール & Liq. \\
コーヒー豆 & 香気成分 & SC. Liq. \\
茶葉 & 香気成分 & SC. Liq. \\
\hline
\end{tabular}

* Liq. : 液体二酸化炭素抽出 SC. : 超臨界二酸化炭素抽出

の後の減圧や昇温等による溶質の析出からなりたつ抽出 プロセスでは，混合物中の着目成分を単離することは困 難である。ここでは超臨界流体を用いて特定成分を精製 する方法について説明する。この分野については現在も 研究が進められており, 今後とも様々な方法が提案され ると思われる。

\section{$3 \cdot 3 \cdot 1$ 還流型超臨界流体抽出装置による脂肪酸エス テルの分離・精製}

超臨界流体は一定圧力下で温度を上げると密度が下がり その溶解力が減少する。この性質を利用して Eisenbach ${ }^{9)}$ や鈴木ら ${ }^{10)}$ は半流通式の還流型超臨界流体抽出装置を 試作し，脂肪酸エステル混合物の精製を行った。Fig. 11 に装置の概要を示す。この装置は抽出器の上部に温度勾 配を付けた濃縮塔が取り付けられており，通常，濃縮塔 の上部の温度は下部よりも高くしてある。抽出器に分離

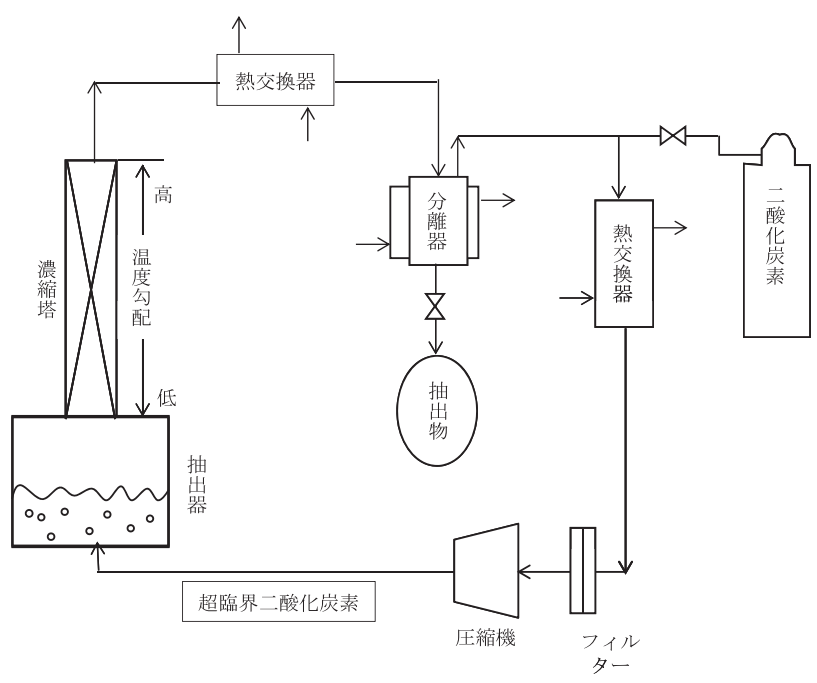

Fig. 11 還流型超臨界流体抽出装置の概要
対象の混合物を仕込み超臨界流体により抽出すると, 溶 解度に応じて超臨界流体中に混合物の成分が抽出され る。この超臨界流体を濃縮塔に入れると, 塔内を上昇す るにつれて超臨界流体の温度が上昇し, その結果, 超臨 界流体の密度が減少して溶解力が低下し, 揮発性の低い 成分の一部が凝縮して, 濃縮塔内を還流する。この還流 効果により, 分子量の小さなエステルから順番に塔頂よ り取り出している。この装置を用いて魚油から得られた 脂肪酸エステルの分留を行った結果, 魚油中の EPAや DHA といった生理活性物質を高純度かつ高収率で得る ことができたと報告している。

\section{$3 \cdot 3 \cdot 2$ 超臨界流体クロマトグラフィーによる脂肪酸 あるいは脂肪酸エステルの分離・精製}

80 年代に超臨界流体クロマトグラフィーが開発され, 新しい分離手法として注目されている ${ }^{11)}$ 。移動相とし て用いている超臨界流体は液体に近い溶解力を持ち, 一 方で気体に近い粘度と液体より 2 3 桁大きい拡散係数 を持っているので，ガスクロマトグラフィーや液体クロ マトグラフィーにはない優れた分離特性を有している。 超臨界流体クロマトグラフィーは生化学物質の分離・精 製技術として幾つかの長所を持っている。すなわち， (1) 高流速でも高分離能が得られるために分取に要する時間 を短縮できる, (2)分取後の移動相と溶質成分の分離は減 圧操作のみでできるため, 溶質の熱変性や移動相に用い た流体の残留の心配がないなどである。その一方, (3)移 動相として超臨界二酸化炭素を用いると, その溶解力の 制約のために, 強い極性を持つ物質や分子量が大きな高 分子に適用できない。私達が得た経験から判断して, 超 臨界二酸化炭素を移動相として用いた場合, 分子量が 1,000 以下の極性のあまり大きくない物質が分取の対象 
Table 3 超臨界流体クロマトグラフィーによる $\gamma$-リノレン酸 $\left(\mathrm{C}_{18: 3}\right)$ の濃縮（原料…糸状菌生産油脂, 収率...990 98\%)

\begin{tabular}{|l|c|c|c|c|c|c|c|c|c|c|}
\hline \multirow{2}{*}{ 試料 } & \multicolumn{5}{|c|}{ クロマト分離前 (\%) } & \multicolumn{4}{c|}{ クロマト分離後 $(\%)$} \\
\cline { 2 - 12 } & $16: 0$ & $16: 1$ & $18: 0$ & $18: 1$ & $18: 2$ & $18: 3$ & $16: 0$ & $16: 1$ & $18: 2$ & $18: 3$ \\
\hline 脂肪酸メチル & 30.0 & 0.5 & 4.1 & 51.8 & 7.2 & 5.3 & 2.8 & 1.8 & 1.2 & 94.2 \\
\hline 脂肪酸 & 30.1 & 1.4 & 5.4 & 45.7 & 9.3 & 5.8 & 1.9 & 1.0 & 1.6 & 95.5 \\
\hline
\end{tabular}

*先頭の数字は, 脂肪酸あるいはエステルを構成する脂肪酸の炭素数を, 後の数字は二重結合の数を表す。

\section{として適していると思われる。}

私達は超臨界流体クロマトグラフィーを用いて脂肪酸 あるいは脂肪酸エステル混合物中の生理活性を有する特 定成分の分離・精製を行った ${ }^{12)}$ 。試料は糸状菌生産油 脂を加水分解またはメチルエステル化して得られた脂肪 酸あるいは脂肪酸エステル混合物と, 魚油のエステル化 により得られた脂肪酸エステル混合物であり，各々の中 には生理活性物質である $\gamma$-リノレン酸，エイコサペン タエン酸とドコサヘキサエン酸が含まれている。分取操 作は, カラム温度 $35 \sim 40^{\circ} \mathrm{C}$, カラム圧力 9 $14 \mathrm{MPa}$ の 条件下で超臨界二酸化炭素を移動相とし, ODS カラム を用いて行った。カラムから留出してきた移動相は，大 気圧まで減圧し移動相中の生理活性物質を析出させた。 クロマト分離にかける前の糸状菌生産油脂中の脂肪酸組 成と分取された画分の組成を Table 3，に示す。高純度 の $\gamma$-リノレン酸あるいは $\gamma$-リノレン酸メチルエステル (試料中の $18: 3$ の成分) が高い収率で得られた。

\section{4 おわりに}

生化学物質の分離および精製に対する超臨界流体の適 用性と応用例の幾つかを説明した。最近この分野では,
より高度な分離が可能な分離手法や, 反応と分離の複合 化によるプロセスの簡素化や省エネルギー化等の研究開 発が進められており, 今後の一層の発展が期待される。

\section{文献}

1）化学工学会超臨界流体部会（編）, 超臨界流体入門, p.67-84，丸善 (2008)

2）佐古猛，岡島いづみ，超臨界流体のはなし，p.78-82, 119-122，日刊工業新聞社（2006）

3）長浜邦雄, 化学工学, 47, 206-212（1983）

4) E. Stahl et al., Extraction with Supercritical Gases, (edited by G. M. Schneider et al.), Verlag Chemie, p.93-114 (1980)

5）荒井康彦（監修)，超臨界流体のすべて，p.365-399，テ クノシステム (2002)

6）長浜邦雄，鈴木功（編）, 食品への超臨界流体応用ハン ドブック, p.11-16, サイエンスフォーラム (2002)

7）小林猛, ケミカルエンジニヤリング, 30, 446-452（1985）

8）佐古猛ら, 油化学, 35, 463-466 (1986)

9) W. Eisenbach, Ber. Bunsenges. Phy. Chem., 88, 882 (1984)

10）鈴木康夫ら，化学工学論文集，15，439-445（1989）

11）化学工学会超臨界流体部会（編）, 超臨界流体入門, p.85-91，丸善 (2008)

12）榊啓二, 佐古猛ら, 油化学, 36，943-946（1987） 